\title{
Relationship between physical activity and functional capacity change in aged cohort in São Paulo, Brazil
}

\author{
Relação entre atividade física e mudança na capacidade funcional numa coorte de idosos em São Paulo, Brasil \\ Relación entre ejercicio físico y cambio en la capacidad funcional en una cohorte de ancianos en São Paulo, Brasil
}

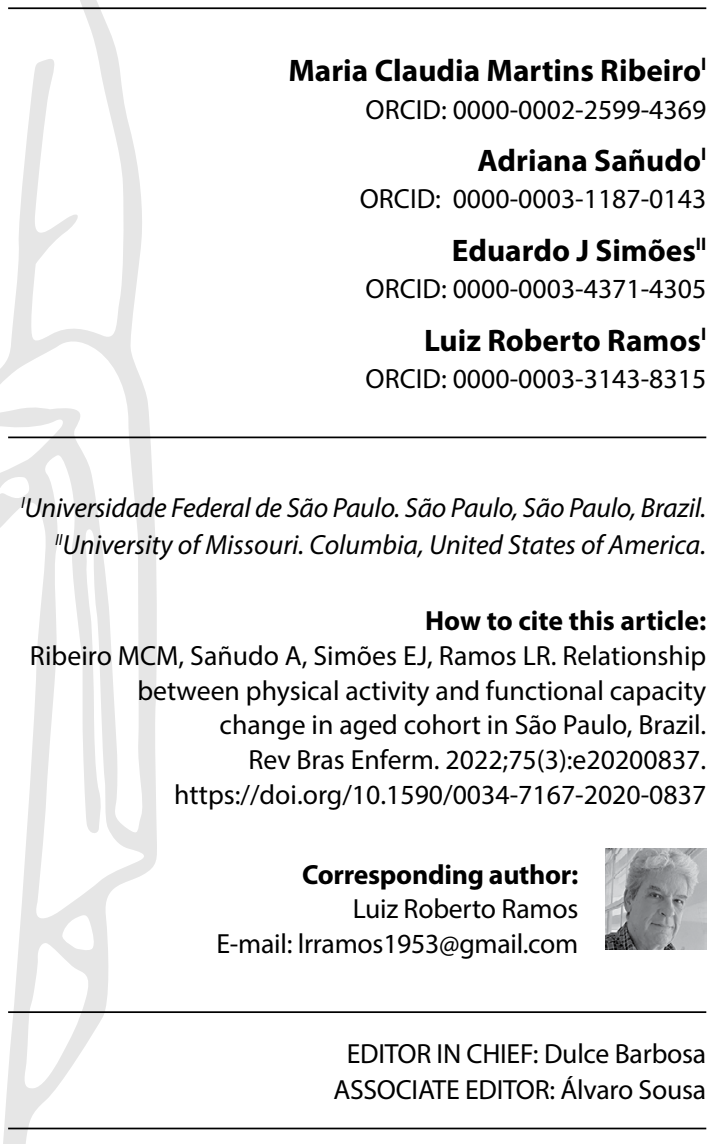

Submission: 09-07-2020

Approval: 08-22-2021

\begin{abstract}
Objectives: to evaluate the relationship between leisure-time physical activity and functional capacity change among aged people. Methods: we analyzed data of an aged cohort looking for determinants of functional capacity at follow-up. Baseline data were collected between 2007 and 2008 - average follow-up of 3,5 years. A full multivariate linear regression model was built to evaluate functional capacity at the end of the follow-up, controlling for functional capacity at baseline, sociodemographic, health and behavioral characteristics and amount of leisure-time physical activity in the period. Results: final model showed functional capacity independently correlated with age $(p<0.001)$, body mass $(p=0.013)$ and the number of activities of daily living compromised at baseline $(p<0.001)$. Functional capacity improved with increased physical activity but loss statistical significance after adjustments $(p=0.384)$. Conclusions: functional capacity decreases with increased age, increased loss of functional capacity at baseline and increased body mass. Albeit a non-significant association, leisuretime physical activity appears as an important modifiable factor.
\end{abstract}

Descriptors: Activities of Daily Living; Physical Activity; Cohort Study; Aging; Health Determinants.

\section{RESUMO}

Objetivos: avaliar a relação entre atividade física de lazer e mudança de capacidade funcional entre idosos. Métodos: analisamos dados de uma coorte de idosos em busca de determinantes da capacidade funcional no seguimento. Dados da linha de base foram coletados entre 2007 e 2008 - acompanhamento médio de 3,5 anos. Foi construído um modelo de regressão linear multivariado completo para avaliar a capacidade funcional ao final do seguimento, controlando pela capacidade funcional na linha de base, características sociodemográficas, de saúde e comportamentais e quantidade de atividade física no período. Resultados: o modelo final mostrou capacidade funcional independentemente correlacionada com a idade $(p<0,001)$, massa corporal $(p=0,013)$ e número de atividades de vida diária comprometidas na linha de base $(p<0,001)$. Capacidade funcional melhorou com o aumento da atividade física, mas perdeu significância estatística após ajustes $(p=0,384)$. Conclusões: capacidade funcional diminui com o aumento da idade, o aumento da perda da capacidade funcional na linha de base e o aumento da massa corporal. Embora não significativamente associada, a atividade física no lazer aparece como um importante fator modificável.

Descritores: Atividades de Vida Diária; Atividade Física; Estudo de Coorte; Envelhecimento; Determinantes de Saúde.

\section{RESUMEN}

Objetivos: evaluar la relación entre ejercicio físico de ocio y cambio de capacidad funcional entre ancianos. Métodos: analizamos datos de una cohorte de ancianos en búsqueda de determinantes de la capacidad funcional en el seguimiento. Datos de la línea de base fueron recolectados entre 2007 y 2008 - acompañamiento mediano de 3,5 años. Fue construido un modelo de regresión linear multivariado completo para evaluar la capacidad funcional al fin del seguimiento, controlando por la capacidad funcional en la línea de base, características sociodemográficas, de salud y conductas y cantidad de ejercicio físico en el período. Resultados: el modelo final mostró capacidad funcional independientemente correlacionada con la edad $(p<0,001)$, masa corporal $(p=0,013)$ y número de actividades cotidianas comprometidas en la línea de base $(p<0,001)$. Capacidad funcional mejoró con el aumento del ejercicio físico, pero perdió significación estadística después de ajustes $(p=0,384)$. Conclusiones: capacidad funcional disminuyó con el aumento de la edad, el aumento de la perdida de la capacidad funcional en la línea de base y el aumento de la masa corporal. Aunque no significativamente relacionado, el ejercicio físico en el ocio aparece como un importante factor cambiable. Descriptores: Actividades de la Vida Diaria; Actividad Física; Estudio de Cohorte; Envejecimiento; Determinantes de Salud. 


\section{INTRODUCTION}

The world's aged population is increasing substantially at a fast pace, especially in developing countries ${ }^{(1)}$. In 2025, Brazil will have more than 30 million people over the age of 60 , representing about $16 \%$ of the population and the projection is that by 2050 one in five people will be 60 years old or more - we will have more aged people than children in the country ${ }^{(2-3)}$.

As the population ages, we observe a change in the health profile characterized by the emergence of chronic non-communicable diseases (NCDs), all potentially disabling and directly related to age and lifestyle ${ }^{(4)}$. The vast majority of the elderly refer some chronic condition that can compromise the ability to perform daily activities, with loss of independence and autonomy and consequent decrease in functional capacity $(\mathrm{FC})^{(5)}$. FC is, in fact, an important risk factor for mortality and there is evidence that aged people with a higher degree of dependence in daily life have a greater risk of dying than independent ones ${ }^{(6-7)}$. Several studies have shown that $\mathrm{FC}$, in turn, is associated with sociodemographic, health and behavioral factors such as age, gender, education, income, number of diagnosis, body mass, smoking, drinking and exercising ${ }^{(8-12)}$.

The $\mathrm{WHO}^{(13)}$ identifies physical inactivity as the fourth main risk factor for global mortality and points to physical activity (PA) as one of the main determinants of active aging with evidence in improving quality of life, reducing disability, maintaining FC and promoting longevity. The relationship between PA and the health status of the elderly is well established and has been pointed out by countless studies that demonstrate its physical, social, psychological and functional benefits ${ }^{(8,14-15)}$.

Despite the evidences in favor of PA, the majority the aged population is inactive. In Brazil, only $22.3 \%$ of the elderly meet the recommended levels ( $\geq 150 \mathrm{~min} /$ week) of leisure-time physical activity (LTPA) $)^{(4)}$. High inactivity rates, however, are also found in Sweden $(71.4 \%)^{(14)}$; in Ghana $(78 \%)^{(16)}$; in the United States (84\%) (17); and in the world $(72.5 \%)^{(18)}$.

LTPA has been considered a good practical indicator of the person's physical activity in daily life, as it indicates a favorable health behavior that can be modified by health promotion campaigns and public health policies ${ }^{(19)}$.

It is important for public health to better understand the relation between LTPA and changes in FC in old age, controlling for all the social, behavioral and health characteristics of the aged population, since the evidences are often cross-sectional ${ }^{(8-10)}$. Such knowledge will instruct the planning of public policies for prevention and health promotion for the aged, aiming at the Sustainable Development Goals (SDGs) in Brazil, that propose, among others, to promote mental health and well-being for everyone, at all ages and to reduce by one third the premature mortality from non-communicable diseases via prevention and treatment, by $2030^{(20)}$.

\section{OBJECTIVES}

To evaluate the relationship between leisure-time physical activity and functional capacity change among aged people.

\section{METHODS}

\section{Ethic}

This work was analyzed and approved by the Research Ethics Committee (CEP/UNIFESP/HSP) on 11/14/2017 (0984/2017).

\section{Study design}

This study, guided by the STROBE tool, used secondary data from the EPIDOSO Project ${ }^{(21)}$, a population cohort study with a representative sample of an aged population living in an uppermiddle class neighborhood in the city of São Paulo, with a high educational level. The study was coordinated by the Center for the Study of Aging at the Federal University of São Paulo (UNIFESP), and baseline data collected between December 2007 and April 2008 , with an average follow-up period of 3.5 years ${ }^{(21)}$.

\section{Sample}

A census in the area identified 1.498 people aged 60 or more, all invited to participate ${ }^{(21)}$. A total of 907 subjects underwent a Comprehensive Geriatric Assessment (CGA) at baseline, including an assessment of FC and LTPA. The present study included only those who had data on FC and LTPA at follow-up $(n=287)$.

\section{Protocol}

\section{Dependent variable}

The outcome variable of this study was FC, measured at follow-up by the number of ADL that the aged needed help to perform (ADL2), using a previously validated instrument with $15 \mathrm{ADL}(\mathrm{BOMFAQ})^{(22)}$. FC was analyzed as a continuous variable with a score ranging from 0 (total independence) to 15 (total dependence).

\section{Independent variables}

The main independent variable was LTPA measured by the long form of the International Physical Activity Questionnaire IPAQ version $8^{(23)}$, the instrument most often used to quantify and compare the levels of PA in different populations, validated in 12 countries, including Brazil ${ }^{(24)}$. LTPA was a continuous variable, expressing the time in minutes spent per week at different activities and intensities. The evolution of LTPA was summarized by the median value obtained between the LTPA result at the baseline and at the end of the follow-up (LTPA $\left.{ }_{\mathrm{P} 50 \%}\right)$. In the absence of repeated follow up surveys with LTPA measurement, is a recommended practice for longitudinal studies, the variable LTPAP50\% that captures the expected change in LTPA over time. A change in LTPA (follow up minus baseline measure) was also evaluated in sensitivity analysis ${ }^{(25-26)}$.

Other independent variables known to interfere with $\mathrm{FC}$ were obtained from CGA and included in the analysis: gender (male / female); age (in years); marital status (not married / married); schooling ( $\leq 8$ years $/>8$ years); income (in minimum wages); 
body mass index (in $\mathrm{kg} / \mathrm{m}^{2}$ ); number of diagnoses (in numbers); drugs used (in numbers); fall (absent / present); dysthymia (absent / present - assessed by Geriatric Depression Scale $\left.{ }^{(27)}\right)$; alcohol consumption (yes / no); tobacco consumption (yes / no); baseline FC (baseline ADL, hereafter labeled ADL1).

\section{Statistical analysis}

A descriptive analysis was performed where categorical variables were summarized by the number $(\mathrm{N})$ and percentage (\%) and non-categorical variables as mean \pm standard deviation or as median (P50\%) and interquartile range (P25\%; P75\%) when the normality assumption was not satisfied.

A full multivariate linear regression model was built in two stages to evaluate the association of the dependent variable FC at the end of the follow-up (ADL2) with explanatory variables in the baseline, including FC at baseline (ADL1) and LTPAP50\%. In the first stage, a simple linear regression model (bivariate analysis) of the dependent variable, FC at the end of the follow-up (ADL2), with each explanatory variable (covariates) at baseline, including $\mathrm{LTPA}_{\mathrm{P5} 0 \%}$ and ADL1, were evaluated. From this bivariate analysis, all variables that had a $p$ value less than $0.20(p<0.20)$ were included in the Multiple Linear Regression model. Explanatory variables that were not significant in this multilinear model ( $p$-value $>0.05$ for bilateral statistical test) were removed one by one until the final adjusted model was reached, where those that remained statistically correlated with the ADL2 remained. The adjustment of the multiple linear regression model allowed the control of possible confounding variables that could bias the results. The $\mathrm{LTPA}_{\mathrm{P} 50 \%}$ and ADL1 variables remained in all modeling steps, including the final adjustment, despite their level of statistical significance. This model building strategy is epidemiologically recommended ${ }^{(28)}$.

In addition, the use of baseline outcome measure (ADL1) as an independent factor (predictor or adjusting) in the regression model for evaluating outcome (ADL2) change from baseline to follow up time, is recommended ${ }^{(29-30)}$. A proportional odds (ordinal) regression was also used to evaluate the associations of $F C$ at follow up (ADL2) with predictors, especially LTPA, fully adjusted for the same set of covariates in the final linear regression model.
Though this study dependent variable (ADL2) is ordinal, it entered all linear regression models (bivariate and multivariate) as ordinal approximation of a continuous variable for three reasons. First, ordinal variables with five or more categories can often be used as continuous without any harm to the analysis, especially if relationship is linear. Second, linear regression models can be more stable than ordinal regression models. Finally, linear regression models are easier to interpret ${ }^{(30-31)}$.

\section{RESULTS}

Among the 287 participants, $50 \%$ did not reach the recommended levels of LTPA (up to 75 minutes/median week) between the evaluations. Most of the elderly were women (66\%), with a stable union (52\%), more than 8 years of study (70\%), with a median income equal to 4.3 minimum wages, ranging from no income to 43 minimum wages. The average age was approximately 72 years (ranging from 60 to 89 years). Among the health-related characteristics, it was observed that the mean BMl was $27.3 \pm 4.7 \mathrm{Kg} / \mathrm{m}^{2}$, indicating that the majority of the elderly were eutrophic; on average, the elderly consumed 5 drugs per day with a range from none to twelve, and presented approximately 8 medical diagnoses with a range from none to twenty. It was found that $23 \%$ and $24 \%$ had dysthymia and a history of falls, respectively. Among the behavioral variables, $95 \%$ did not smoke and $61 \%$ did not consume alcohol.

Table 1 shows the result of the bivariate analysis, where it is observed that, except for alcohol and tobacco consumption, all variables showed a significant relationship with the ADL2. The $\mathrm{LTPA}_{\mathrm{P} 50 \%}$ showed an inverse and significant relationship with the FC, indicating that, for each additional minute per week of LTPA, the ADL2 score decreases 0.003 .

Table 2 shows the initial adjustment of the multiple linear regression of the ADLs at the end of the follow-up with the selected variables, to examine which of them were independently associated with the outcome. The results indicate that the variables gender, marital status, education, income, number of diagnoses, number of medications, fall, dysthymia and LTPA $_{\mathrm{P} 50 \%}$ lost their significance when analyzed together, that is, they were not independently correlated with AVD2 ( $p>0.05)$. The variables age, BMI and ADL1 remained significant.

Table 1 - Result of the simple linear regression model for the dependent variable number of limitations in the activities of daily living, São Paulo, São Paulo, Brazil, 2019

\begin{tabular}{|c|c|c|c|c|}
\hline Independent variables & Coefficient ( $\beta$ ) & Standard error & $95 \% \mathrm{Cl}$ & p-value \\
\hline Gender, feminine & 0.958 & 0.392 & $0.187 ; 1.729$ & 0.015 \\
\hline Age, years & 0.175 & 0.025 & $0.126 ; 0.224$ & $<0.001$ \\
\hline Marital status, not married & 0.843 & 0.370 & $0.114 ; 1.572$ & 0.024 \\
\hline Education, $<8$ years & 1.091 & 0.402 & $0.299 ; 1.883$ & 0.007 \\
\hline Income, minimum wage & -0.058 & 0.023 & $-0.104 ;-0.012$ & 0.013 \\
\hline Diagnostics, number & 0.212 & 0.044 & $0.125 ; 0.299$ & $<0.001$ \\
\hline Medicines, number & 0.263 & 0.061 & $0.141 ; 0.384$ & $<0.001$ \\
\hline Fall, present & 1.358 & 0.432 & $0.509 ; 2.208$ & 0.002 \\
\hline Dysthymia, number & 0.207 & 0.059 & $0.090 ; 0.324$ & $<0.001$ \\
\hline $\mathrm{BMI}, \mathrm{kg} / \mathrm{m}^{2}$ & 0.180 & 0.039 & $0.102 ; 0.258$ & $<0.001$ \\
\hline Tobacco, yes & -0.423 & 0.420 & $-1.251 ; 0.404$ & 0.315 \\
\hline Alcohol, yes & -0.450 & 0.384 & $-1.207 ; 0.307$ & 0.243 \\
\hline LTPA $_{\mathrm{P} 50 \%}$, minutes & -0.003 & 0.001 & $-0.005 ;-0.001$ & 0.003 \\
\hline ADL1, number & 0.542 & 0.062 & $0.420 ; 0.664$ & $<0.001$ \\
\hline
\end{tabular}


Table 2 - Result of the initial adjustment of the multiple linear regression model for the dependent variable number of limitations in the activities of daily living, São Paulo, São Paulo, Brazil, 2019

\begin{tabular}{|c|c|c|c|c|}
\hline Independent variables & Coefficient ( $\beta$ ) & Standard error & $95 \% \mathrm{Cl}$ & p-value \\
\hline Age, years & 0.130 & 0.026 & $0.078 ; 0,181$ & $<0.001$ \\
\hline Gender, feminine & 0.128 & 0.403 & $-0.665 ; 0.922$ & 0.750 \\
\hline Marital status, not married & 0.306 & 0.356 & $-0.394 ; 1,007$ & 0.390 \\
\hline Education, $<8$ years & 0.186 & 0.384 & $-0.570 ; 0.942$ & 0.628 \\
\hline Income, minimum wage & -0.020 & 0.020 & $-0.063 ; 0.022$ & 0.348 \\
\hline Diagnostics, number & 0.041 & 0.046 & $-0.050 ; 0,124$ & 0.133 \\
\hline Medicines, number & 0.064 & 0.066 & $-0.065 ; 0.194$ & 0.329 \\
\hline Fall, present & 0.440 & 0.390 & $-0.327 ; 1.208$ & 0.260 \\
\hline Dysthymia, number & 0.088 & 0.058 & $-0.027 ; 0.204$ & 0.136 \\
\hline $\mathrm{BMI}, \mathrm{kg} / \mathrm{m}^{2}$ & 0.094 & 0.391 & $0.017 ; 0.171$ & 0.016 \\
\hline LTPA $_{\mathrm{P} 50^{\circ},}$ minutes & -0.0005 & 0.0010 & $-0.002 ; 0.001$ & 0.624 \\
\hline ADL1, number & 0.296 & 0.076 & $0.146 ; 0.446$ & $<0.001$ \\
\hline
\end{tabular}

Table 3 - Result of the final adjustment of the multiple linear regression model for the dependent variable number of limitations in the activities of daily living, São Paulo, São Paulo, Brazil, 2019

\begin{tabular}{lcccc}
\hline Independent variables & Coefficient $(\boldsymbol{\beta})$ & Standard error & $\mathbf{9 5 \%} \mathbf{C l}$ & $\mathbf{p}$-value \\
\hline Age, years & 0.140 & 0.024 & $0.091 ; 0,188$ & $<0$ \\
$\mathrm{BMI}_{\mathrm{kg}} / \mathrm{m}^{2}$ & 0.937 & 0.037 & $0.019 ; 0.167$ & 0.013 \\
LTPA $_{\mathrm{p} 50 \% \%^{\prime} \text { minutes }}$ & -0.0009 & 0.0010 & $-0.003 ; 0.001$ & 0.384 \\
ADL1, numbers & 0.398 & 0.066 & $0.268 ; 0.529$ & $<0.001$ \\
\hline
\end{tabular}

BMI - body mass index; $A D L$ - activity of daily living; LTPA - leisure-time physical activity.

Table 3 shows the final model with the variables that showed being independently correlated with the ADL2. Even though it is not statistically significant, the variable LTPA $_{P 50 \%}$ remained in the final adjustment because it is the main variable in the study. Table 3 shows that:

- When age increases by 1 year, ADL2 increases by, on average, 0.14 ADLs $(p<0.001)$, that is, in 10 years an average increase of 1.4 in ADL limitations is expected;

- When the BMI increases by $1 \mathrm{Kg} / \mathrm{m}^{2}$, the number of limitations increases by 0.93 ;

- When adding a difficulty in the ADLs in the first assessment, the number of difficulties increases by 0.4 .

- The relationship between $\mathrm{LTPA}_{\mathrm{P} 50 \%}$ and FC remains inverse, but it becomes weaker ( $\beta=-0.0009)$ and statistically not significant.

An ordinal regression of ADL2 on the same set of independent model predictors of the final linear regression produced results like those presented in Tables 2-3 (data not shown).

\section{DISCUSSION}

The relationship between LTPA and FC showed significance only when LTPA was examined as the only independent variable. After adjusting for other confounding variables, this relationship became weaker and not significant, similar to results reported by Cordeiro et al (2014) and Lopez et al (2014)(32-33). Although they do not indicate a significant relationship, the results point to a relationship in the expected direction. When the minutes per week of LTPA increase, the number of difficulties in ADLs decreases. The lack of significance found in this study can perhaps be explained by the fact that some of the explanatory variables selected as influencing FC are also potentially influential in LTPA. Studies carried out by several authors demonstrate that LTPA is related to the same factors that influence $\mathrm{FC}$, that may act either interactive or confounding factor in this type of analysis ${ }^{(15,34-36)}$.

This work, instead of using the median energy expenditure (METs) as suggested by IPAQ ${ }^{(23)}$, used the median time spent in minutes per week, as was done by other studies ${ }^{(37-38)}$. These authors justify that movement and energy patterns differ between age groups and that the weighting factors indicated by the IPAQ correspond to adult metabolic values that are probably not appropriate for the aged. In addition, they point to the fact that the time in minute presents an immediate idea of the PA described and that it is the unit of measurement most commonly used by other instruments.

Similar to LTPA, most independent variables significantly associated with ADL2 in the bivariate analysis, lost their significance after adjustments, with the exception of BMI and ADL1.

The knowledge from multiple reported studies of the relation between $A D L$ and $\mathrm{BMI}^{(39-41)}$, including an extensive review ${ }^{(39)}$, reinforce our interpretation that treating $A D L 2$ as approximately continuous did not harm or bias analysis. The results of this work indicate a significant relationship between $\mathrm{BMI}$ and $\mathrm{FC}$, reinforcing the results of other studies ${ }^{(39-41)}$ and disagreeing with the results found by Ballesteros, Moreno-Montoya (2018) ${ }^{(9)}$ and Matos (2018) (42). This relationship can be explained because obesity is related to low PA on the part of the aged ${ }^{(36,43-44)}$ and by the association between excess body fat and the development of chronic diseases ${ }^{(40)}$, most of the times disabling. The bibliographic review carried out by Jensen and Hsiao (2010) ${ }^{(39)}$ found that, in addition to being strongly related to $\mathrm{BMI}, \mathrm{FC}$ is also related to involuntary changes in body weight, up or down. 
The reduction in $\mathrm{FC}$ with advancing age, as pointed out in this study, is consistently reported in the literature $\mathrm{e}^{(8,11,14,16,40,42,45-46)}$. This relationship is explained by the discrete and constant biological and functional losses characteristic of the aging process that, even if not linear, are associated with age ${ }^{(47)}$.

Studies relating LTPA and FC in aged people have in general a cross-sectional design ${ }^{(8,10,12,36)}$. Our longitudinal design enabled to explore the effect of LTPA on FC over a period of 3,5 years, controlling for all the other risk factors, providing estimates of the risk of changing FC due to the amount of LTPA. Albeit, a nonsignificant association, statistically speaking.

It is important to consider the uniqueness of the sample. It is a population with a high level of education and income, living in a region with a very high Human Development Index (HDI) $(0.970)^{(48)}$, even higher than the HDI of Norway, which leads the UN Human Development ranking $(0.949)^{(49)}$. Despite living in a region with such high social and economic data, the elderly in Vila Mariana District (VMD) showed rates of physical inactivity similar to the rest of the country and the world ${ }^{(18,50)}$. Thus, the present study allowed for a better understanding of the potential determinants of $\mathrm{FC}$ in an aged population living in a region with high social, economic, urban and environmental indicators. The VMD is, in fact, considered an age-friendly neighborhood well supplied with social services, good public transport and a vast network of healthcare, culture and leisure services, that can reduce the risk of functional limitations ${ }^{(51-52)}$. We believe that the results presented may serve as indicators of comparison for other regions with similar characteristics.

\section{Study limitations}

The present study has some limitations. One concerns the instruments used. Both the IPAQ and the BOMFAQ evaluate information obtained through self-reports that can be influenced by cognitive and emotional changes or depend on the individual's ability to remember the activities performed in a certain period of time. Another limitation refers to the small number of evaluations (two) in a relatively long time (average of three and a half years) of variables that change over time such as LTPA, BMI and FC.

As for the small number of participants with longitudinal data ( $n=287$ ), secondary analyzes show that, except for the higher education level in the sample studied, the socio-demographic profile (mean age and sex ratio) of the participants was quite similar to that of the community in which they live ${ }^{(52)}$ (data not shown).

\section{Contributions to the area of Health or Public Policy}

Our results indicate that an increase in LTPA might lead to an improvement in FC, mediated by age and body mass. Considering that scientific evidences point to the benefits of LTPA for maintaining the health of the elderly it is worth investing in public policies that aim to increase the time of LTPA. As a behavioral factor it can be changed and eventually contribute to an active and healthy aging.

\section{CONCLUSIONS}

This work reinforces the multidimensional construct of FC that is related to different variables that, in turn, form a network of factors that relate to each other. It shows that functional capacity in old age decreases with increased age, increased loss of functional capacity at an earlier age and increased BMI.

Despite not being a significant predictive factor of FC in this study, LTPA may be an important factor in this network, since there is strong scientific evidence of its benefits for the promotion and maintenance of the health of the aged. This study raises unique questions regarding the influence of LTPA in the health of aged people that deserve more studies. Besides being confounded by other socio-behavioral and demographic factors, the effect of LTPA on FC in this age group may be mediated interactively by age, $\mathrm{BMI}$, and FC at baseline. The small number of participants and the lack of inter-period measures precluded a detailed analysis of these phenomena with hypothesis testing.

\section{REFERENCES}

1. Veras RP, Oliveira M. Envelhecer no Brasil: a construção de um modelo de cuidado. Ciênc Saúde Colet. 2018;23(6):1929-36. https://doi. org/10.1590/1413-81232018236.04722018

2. Instituto Brasileiro de Geografia Estatística (IBGE). Projeção da População: 2010-2060 [Internet]. 2018 [cited 2020 Sep 6]. Available from: https://agenciadenoticias.ibge.gov.br/agencia-detalhe-de-midia.html?view=mediaibge\&catid=2103\&id=218

3. Simões CCS. Relações entre as alterações históricas na dinâmica demográfica brasileira e os impactos decorrentes do processo de envelhecimento da população[Internet]. Rio de Janeiro: IBGE, Coordenação de População e Indicadores Sociais. 2016 [cited 2020 Sep 6]. Avaliable from: https://biblioteca.ibge.gov.br/visualizacao/livros/liv98579.pdf

4. Ministério da Saúde (BR). Secretaria de Vigilância em Saúde. Vigitel Brasil 2016: vigilância de fatores de risco e proteção para doenças crônicas por inquérito telefônico: estimativas sobre frequência e distribuição sociodemográfica de fatores de risco e proteção para doenças crônicas nas capitais dos 26 estados brasileiros e no Distrito Federal em 2016 [Internet]. 2017 [cited 2020 Sep 6]; Available from: http://www. saude.gov.br/images/pdf/2017/junho/07/vigitel_2016_jun17.pdf

5. Ramos LR. Fatores determinantes do envelhecimento saudável em idosos residentes em centro urbano: Projeto Epidoso, São Paulo. Cad Saúde Pública. 2003;19(3):793-7. https://doi.org/10.1590/S0102-311X2003000300011

6. Ramos LR, Simões EJ, Albert MS. Dependence in activities of daily living and cognitive impairment strongly predicted mortality in older urban residents in Brazil: a 2-year follow-up. J Am Geriatr Soc. 2001;49(9):1 168-75. https://doi.org/10.1046/j.1532-5415.2001.49233.x

7. Lima-Costa MF, Peixoto SV, Matos DL, Firmo JOA, Uchôa E. Predictors of 10-year mortality in a population of community-dwelling Brazilian elderly: the Bambuí cohort study of aging. Cad Saúde Pública. 2011;27(3):360-9. https://doi.org/10.1590/S0102-311X2009000300015 
8. Ribeiro MCM, Sañudo A, Ramos LR. Leisure-time physical activity as a protective factor for functional capacity loss in community dwelling elders. Rev Bras Ciênc Esporte. 2020;42:e2049. https://doi.org/10.1590/rbce.42.2019.278

9. Ballesteros SM, Moreno-Montoya J. Individual- and state-level factors associated with functional limitation prevalence among Colombian elderly: a multilevel analysis. Cad Saúde Pública. 2018;34(8). https://doi.org/10.1590/0102-311x00163717

10. Nunes JD, Saes MO, Nunes BP, Siqueira FCV, Soares DC, Fassa MEG, et al. Indicadores de incapacidade funcional e fatores associados em idosos: estudo de base populacional em Bagé, Rio Grande do Sul. Epidemiol Serv Saúde. 2017;26(2):295-304. https://doi.org/10.5123/ s1679-49742017000200007

11. Artaud F, Sabia S, Dugravot A, Kivimaki M, Singh-Manoux A, Elbaz A. Trajectories of unhealthy behaviors in midlife and risk of disability at older ages in the Whitehall II Cohort Study. J Gerontol A Biol Sci Med Sci. 2016;71(11):1500-6. https://doi.org/10.1093/gerona/glw060

12. Santos JLF, Lebrão ML, Duarte YAO. Desempenho funcional de idosos nas atividades instrumentais da vida diária: uma análise no Município de São Paulo, Brasil. Cad Saúde Pública. 2008;24(4):879-86. https://doi.org/10.1590/S0102-311X2008000400019

13. World Health Organization (WHO). Global recommendations on physical activity for health [Internet]. 2010 [cited 2020 Sep 05]. Available from: https://www.who.int/dietphysicalactivity/global-PA-recs-2010.pdf

14. Rennemark M, Jogréus C, Elmståhl S, Welmer AK, Wimo A, Sanmartin-Berglund J. Relationships between frequency of moderate physical activity and longevity: an 11-year follow-up study. GGM. 2018;4:1-8. https://doi.org/10.1177/2333721418786565

15. Peixoto S, Mambrini J, Firmo J, Loyola Filho A, Souza Jr PR, Andrade F, et al. Physical activity practice among older adults. Rev Saúde Pública. 2019;52(Suppl-2):5s. https://doi.org/10.11606/s1518-8787.2018052000605

16. Fonta CL, Nonvignon J, Aikins M, Nwosu E, Aryeetey GC. Predictors of self-reported health among the elderly in Ghana: a cross sectional study. BMC Geriatr. 2017;17(1):171. https://doi.org/10.1186/s12877-017-0560-y

17. Centers for Disease Control and Prevention (CDC). Adult participation in aerobic and muscle-strengthening physical activities - United States in 2011. MMWR Morbidity Mortality Weekly Report [Internet]. 2013 [cited 2020 Sep 05]; 62(17):326-330. Available from: https://www. cdc.gov/mmwr/preview/mmwrhtml/mm6217a2.htm

18. Guthold R, Stevens GA, Riley LM, Bull FC. Worldwide trends in insufficient physical activity from 2001 to 2016 : a pooled analysis of 358 population-based surveys with 1,9 million participants. The Lancet Global Health. 2018;6(10):1077:1086. https://doi.org/10.1016/ S2214-109X(18)30357-7

19. Hallal PC, Dumith SC, Bastos JP, Reichert FF, Siqueira FV, Azevedo MR. Evolução da pesquisa epidemiológica em atividade física no Brasil: revisão sistemática. Rev Saúde Pública. 2007;41(3):453-60. https://doi.org/10.1590/\$0034-89102007000300018

20. Programa das Nações Unidas para o Desenvolvimento (PNUD). Objetivos de Desenvolvimento Sustentável [Internet]. 2021 [cited 2021 Aug 10] Available from: https://www.br.undp.org/content/brazil/pt/home/sustainable-development-goals.html

21. Ramos LR, Andreoni S, Coelho-Filho JM, Lima-Costa MF, Matos DL, Rebouças M, et al. Screening for dependence in activities of daily living in the elderly: minimum set of questions. Rev Saúde Pública. 2013;47(3):506-13. https://doi.org/10.1590/S0034-8910.2013047004325

22. Rebouças M, Coelho-Filho JM, Veras RP, Lima-Costa MF, Ramos LR. Validity of questions about activities of daily living to screen for dependency in older adults. Rev Saúde Pública. 2017;51:84. https://doi.org/10.11606/S1518-8787.2017051006959

23. IPAQ. Guideness for data processing and analysis of the International Physical Activity Questionaire (IPAQ) - short and long forms. [Internet]. 2005 [cited 2020 Sep 5] Available from: www.ipaq.ki.se.

24. Hallal PC, Victora CG. Reliability and validity of the international physical activity questionnaire (IPAQ). Med Sci Sports Exerc. 2004;36(3):556. https://doi.org/10.1249/01.mss.0000117161.66394.07

25. Hermansen R, Broderstad AR, Jacobsen BK, Mähönen M, Wilsgaard T, Morseth B. The impact of changes in leisure time physical activity on changes in cardiovascular risk factors: results from The Finnmark 3 Study and SAMINOR 1, 1987-2003. Int J Circumpolar Health. 2018;77(1):1459145. https://doi.org/10.1080/22423982.2018.1459145

26. Lahti J, Holstila A, Mänty M. Changes in leisure time physical activity and subsequent disability retirement: a register-linked cohort study. Int J Behav Nutr Phys Act. 2016;13:99. https://doi.org/10.1186/s12966-016-0426-2

27. Paradela EMP, Lourenço RA, Veras RP. Validação da escala de depressão geriátrica em um ambulatório geral. Rev Saúde Pública. 2005;39(6):918-23. https://doi.org/10.1590/S0034-89102005000600008

28. Greenland S. Invited commentary: variable selection versus shrinkage in the control of multiple confounders. Am J Epidemiol. 2008;167(5):523-9;530-1. https://doi.org/10.1093/aje/kwm357

29. Vickers AJ, Altman DG. Analysing controlled trials with baseline and follow up measurements. BMJ. 2001;323:1123. https://doi.org/10.1136/ bmj.323.7321.1123

30. Norman, G. Likert scales levels of measurement and the "laws" of statistics. Adv Health Sci Educ. 2010;15(5): 625-32. https://doi.org/10.1007/ s10459-010-9222-y

31. Sullivan G, Artino JrAR. Analyzing and interpreting data from likert-type scales. J Grad Med Educ. 2013;5(4):541-42. https://doi.org/10.4300/ JGME-5-4-18

32. Cordeiro J, Del Castillo BL, Freitas CS, Gonçalves MP. Efeitos da atividade física na memória declarativa, capacidade funcional e qualidade de vida em idosos. Rev Bras Geriatr Gerontol. 2014;17(3):541-52. https://doi.org/10.1590/1809-9823.2014.13006 
33. López SR, Montero P, Carmenate M, Avendano M. Functional decline over two years in older Spanish adults: evidence from SHARE. Geriatr Gerontol Int 2014;14(2):403-12. https://doi.org/10.1111/ggi.12115

34. Foong YC, Aitken D, Winzenberg T, Otahal P, Scott D, Jones $G$. The association between physical activity and reduced body fat lessens with age-results from a cross-sectional study in community dwelling older adults. Exp Gerontol. 2014;55:107-12. https://doi.org/10.1016/j. exger.2014.04.006

35. Hamer M, Lavoie KL, Bacon SL. Taking up physical activity in later life and healthy ageing: the English longitudinal study of ageing. Br J Sports Med. 2014;48(3):239-43. https://doi.org/10.1136/bjsports-2013-092993

36. Santos CES, Manta SW, Maximiano GP, Confortin SC, Benedetti TRB, d' Orsi E, et al. Accelerometer-measured physical activity and sedentary behavior: a cross-sectional study of Brazilian older adults. J Physic Activity Health. 2018;1-8. https://doi.org/10.1123/jpah.2017-0456

37. Hurtig-Wennlof A, Hagstromer M, Olsson LA. The international physical activity questionnaire modified for the elderly: aspects of validity and feasibility. Public Health Nutrit. 2010;13(11):1847-54. https://doi.org/10.1017/S1368980010000157

38. Mazo GZ, Benedetti TRB. Adaptação do questionário internacional de atividade física para idosos. Rev Bras Cineantropom Desemp Hum. 2010;12(6):480-4. https://doi.org/10.1590/S1980-00372010000600013

39. Jensen GL, Hsiao PY. Obesity in older adults: relationship to functional limitation. Curr Opin Clin Nutr Metab Care. 2010;13(1):46-51. https:// doi.org/10.1097/MCO.0b013e32833309cf

40. Chen YM, Tu YK, Yu HW, Chiu TY, Chiang TL, Chen DR, et al. Leisure time activities as mediating variables in functional disability progression: an application of parallel latent growth curve modeling. PLoS ONE. 2018;13(10): e0203757. https://doi.org/10.1371/journal.pone.0203757

41. Visser M. Obesity, sarcopenia and their functional consequences in old age. Proc Nutr Soc. 2011;70(1):114-8. https://doi.org/10.1017/ S0029665110003939

42. Matos FS, Jesus CS, Carneiro JAO, Coqueiro RS, Fernandes MH, Brito TA. Reduced functional capacity of community-dwelling elderly: a longitudinal study. Ciênc Saúde Coletiva. 2018;23(10):3393-401. https://doi.org/10.1590/1413-812320182310.23382016

43. Zbrońska I, Mędrela-Kuder E. The level of physical activity in elderly persons with overweight and obesity. Rocz Panstw Zakl Hig. 2018;69(4):369-73. https://doi.org/10.32394/rpzh.2018.0042

44. Asp M, Simonsson B, Larm P, Molarius A. Physical mobility, physical activity, and obesity among elderly: findings from a large populationbased Swedish survey. Public Health. 2017;147:84-91. https://doi.org/10.1016/j.puhe.2017.01.032

45. Zhang W, Feldman MW, Du P. Process of decline in activities of daily living of older chinese people prior to death: evidence from three cohorts. Res Aging. 2019;41(8):727-50. https://doi.org/10.1177/0164027519841016

46. Lima-Costa MF, Andrade FB, Souza PRB. The Brazilian Longitudinal Study of Aging (ELSI-Brazil): objectives and design. Am J Epidemiol. 2018;187(7):1345-53. https://doi.org/10.1093/aje/kwx387

47. World Health Organization (WHO). Relatório mundial de envelhecimento e saúde [Internet]. 2015 [cited 2020 Sep 05]. Avaliable from: https://apps.who.int/iris/bitstream/handle/10665/186468/WHO_FWC_ALC_15.01_por.pdf\%3Bjse. Portuguese.

48. Município de São Paulo. Atlas do Trabalho de Desenvolvimento do Município de São Paulo [Internet]. 2007 [cited 2020 Sep 05]. Avaliable from: http://atlasmunicipal.prefeitura.sp.gov.br. Portuguese.

49. Programa das Nações Unidas para o Desenvolvimento (PNUD). Relatório de desenvolvimento humano global [Internet]. 2016 [cited 2020 Sep 05]. Available from: http://www.br.undp.org/content/dam/brazil/docs/RelatoriosDesenvolvimento/undp-br-2016-humandevelopment-report-2017.pdf

50. Ministério da Saúde (SP). Secretaria de Vigilância em Saúde. Vigitel Brasil 2016: vigilância de fatores de risco e proteção para doenças crônicas por inquérito telefônico: estimativas sobre frequência e distribuição sociodemográfica de fatores de risco e proteção para doenças crônicas nas capitais dos 26 estados brasileiros e no Distrito Federal em 2016 [Internet]. 2017 [cited 2020 Sep 05]. Available from: http:// bvsms.saude.gov.br/bvs/publicacoes/vigitel_brasil_2016_fatores_risco.pdf

51. Rosa TEC, Brêtas ACP, Keinert TMM, Novais F, Trench B, Louvision MCP, et al. Implantação do bairro amigo do idoso da Vila Clementino do município de São Paulo/SP. In: Instituto de Saúde. Velhices: experiências e desafios nas políticas do envelhecimento ativo. São Paulo: Instituto de Saúde, 2013; p.137-47

52. Secretaria Municipal de Direitos Humanos e Cidadania. Cidade de São Paulo. Indicadores sociodemográficos da população idosa na cidade de São Paulo[Internet]. 2019 [cited 2020 Sep 05]. Available from: https://www.prefeitura.sp.gov.br/cidade/secretarias/upload/direitos_ humanos/IDOSO/PUBLICACOES/Indicadores\%20sociais_10_02_2020\%20(3).pdf 